\title{
Acetaldehyde binds to liver cell membranes without affecting membrane function
}

\author{
R E BARRY, J D MCGIVAN, AND M HAYES \\ From the Departments of Medicine and Biochemistry, Bristol Royal Infirmary, Bristol
}

SUMMARY Acetaldehyde is a major metabolic product of ethanol and is found in high concentrations in the serum during alcohol abuse. The effects of acetaldehyde on isolated rat liver cells and on purified hepatocyte plasma membrane vesicles have been studied. In concentrations of 0-10 millimolar acetaldehyde has been shown to have no detectable effect on either hepatocyte metabolism or gross membrane function and is therefore unlikely to act as a direct metabolic poison. Acetaldehyde, however, is shown to bind to hepatocyte membranes via intermediary Schiff's base formation. The adduction of acetaldehyde to liver cell plasma membranes may have an effect on membrane structure. These findings are consistent with the hypothesis that any injurious effect of acetaldehyde on the liver may be mediated via the immune system rather than being a direct effect on cell metabolism.

In spite of extensive studies, the mechanism by which alcohol can produce liver damage in susceptible individuals is unknown. The vast majority of the research into alcoholic liver disease, however, has concentrated on the biochemical and ultrastructural effects of alcohol and its metabolic products inside the liver cells. This approach has contributed very little to our understanding of the aetiology of alcoholic liver disease. It is becoming increasingly recognised, however, that immunological mechanisms may play a role in the aetiology of this type of liver damage ${ }^{1}$ and this subject has recently been reviewed. ${ }^{2}$ If immunological mechanisms are involved in the initiation of alcoholic liver damage, then the effects of alcohol abuse should be manifest on the cell surface of the hepatocyte - that is, the plasma membrane - in order to initiate the immune response.

Acetaldehyde is a highly reactive molecule and the immediate metabolic product of ethanol. It is found in high concentrations in the serum of patients who abuse ethanol. It has been suggested that acetaldehyde may be the factor which precipitates liver damage in alcoholic liver disease. We have therefore studied the effects of acetaldehyde on isolated rat hepatocytes with particular reference to the effects on the hepatocyte plasma membrane.

Address for correspondence: Dr R F Barry. Dept of Medicine. Bristol Royal Infirmary. Bristol BS2 9HW

Received for publication 6 July 1983

\section{Methods}

Plasma membrane vesicles were prepared from the livers of female Wistar rats by the method of Van Amelsvoort $\mathrm{et}^{\mathrm{al}} \mathrm{l}^{3}$ using a discontinuous gradient prepared from $46.5 \%(\mathrm{w} / \mathrm{v})$ sucrose and $21.5 \%(\mathrm{w} / \mathrm{v})$ sucrose in $10 \mathrm{mmol}$ Hepes/KOH at $\mathrm{pH} 7 \cdot 5 .^{4}$ Immediately after preparation the plasma membrane vesicles were frozen in liquid nitrogen and stored at $-20^{\circ} \mathrm{C}$ until used.

The efficiency of the preparation procedure was assessed by assay in the preparation of the specific activity of $5^{\prime}$ nucleotidase (using the method of Hepel and Himlow ${ }^{5}$ and glucose-6-phosphate (using the method described by Swanson ${ }^{6}$ ). Protein assays in the vesicle preparations were measured by the method of Lowry.

If acetaldehyde binds to the proteins of the liver cell plasma membrane it is likely that this occurs via the formation of an intermediary Schiff base with the free amino group of the lysine residues in the same way that has been shown for the aldehyde forms of reducing sugars reacting with proteins such as haemoglobin.

$\mathrm{RNH}_{2}+\mathrm{CH}_{3} \mathrm{C}_{\mathrm{O}}^{-\mathrm{H}} \rightleftharpoons \mathrm{RN}-\mathrm{CH}_{2} \mathrm{OH} \rightleftharpoons \mathrm{RN}=\mathrm{CH}_{2}$

Any Schiff bases so formed can be reduced specifically with sodium cyanoborohydride ${ }^{8}$ to form 
a covalent bond thus incorporating the tritium label into the protein. ${ }^{9}$

$$
\mathrm{R}-\mathrm{N}=\mathrm{CHCH}_{3} \stackrel{\mathrm{NaCNBH}_{3}{ }^{*}}{\longrightarrow} \mathrm{R}-\stackrel{\stackrel{\mathrm{H}^{*}}{\mathrm{~N}}-\stackrel{\mathrm{H}}{\mathrm{C}}-\mathrm{CH}_{3}}{\mathrm{H}^{*}}
$$

The binding of acetaldehyde to liver cell membrane vesicles was therefore studied using the incorporation of tritium from tritiated sodium cyanoborohydrite as follows.

Liver plasma membrane vesicles containing approximately $1 \mathrm{mg}$ protein were incubated at $18^{\circ} \mathrm{C}$ for 10 hours in a total volume of $1 \mathrm{ml}$ containing 100 $\mathrm{mM}$ Hepes buffer $\mathrm{pH} 7 \cdot 5,2 \mathrm{mM}$ nickel chloride, ${ }^{10}$ $20 \mathrm{mM}$ tritium-labelled sodium cyanoborohydride and acetaldehyde concentrations of $0-1 \mathrm{mM}$. After 10 hours the reaction was stopped by the addition of $50 \mu \mathrm{l}$ of perchloric acid. The precipitated proteins were spun down and washed three times in cold 20 $\mathrm{mM}$ sodium cyanoborohydride. After washing, the protein was dissolved in $250 \mu \mathrm{l}$ of formic acid and the activity was determined by liquid scintillation counting in Unisolve $E$ (Koch Light Laboratories Ltd) using a Nuclear Chicago Isocap 3 Liquid Scintillation Counter.

Isolated liver cells were prepared from the livers of male Wistar rats by the method of Berry and Friend $^{11}$ as modified by Krebs et al. ${ }^{12}$ The hepatocytes were incubated in Krebs-Henseleit bicarbonate buffered medium together with the appropriate substrate with or without acetaldehyde, at $37^{\circ} \mathrm{C}$ and $\mathrm{pH} 7 \cdot 4$.

The cells were deproteinised after a given time by the addition of perchloric acid $(3.5 \% \mathrm{w} / \mathrm{v})$ and urea and glucose production were measured in the neutralised extract by standard enzymic methods. ${ }^{1314}$

The leakage of lactate dehydrogenase from isolated liver cell preparations from fed rats was estimated after 40 minutes' incubation with acetaldehyde in concentrations up to $20 \mathrm{mM}$, by centrifuging the incubation mixture at $10000 \mathrm{~g}$ for five seconds, and assaying the lactate dehydrogenase in the supernatant as described previously. ${ }^{15}$

Alanine transport by the isolated liver cells was measured as described by Joseph et al ${ }^{16}$ using isolated liver cells prepared from rats fasted overnight, $0.5 \mathrm{mM}$ alanine as substrate, and an incubation time of two minutes in Krebs-Henseleit bicarbonate buffered medium containing 0-20 mM acetaldehyde.

\section{Results}

The purity of the liver plasma membrane vesicles may be assessed from the Table. The results are
Table Efficiency of the preparative procedure as assessed by membrane marker enzymes ( $\mu \mathrm{mol} / \mathrm{h} / \mathrm{mg}$ protein)

\begin{tabular}{lll}
\hline & $\begin{array}{l}\text { Whole } \\
\text { liver } \\
\text { homogenate }\end{array}$ & $\begin{array}{l}\text { Liver } \\
\text { plasma } \\
\text { membrane } \\
\text { vesicles }\end{array}$ \\
\hline $\begin{array}{l}5 \text { nucleotidase (plasma } \\
\text { membrane marker) }\end{array}$ & $4 \cdot 7 \pm 1 \cdot 1$ & $26 \cdot 1 \pm 0 \cdot 15$ \\
$\begin{array}{l}\text { Glucose } 6 \text { phosphatasc } \\
\text { (endoplasmic reticulum } \\
\text { marker) }\end{array}$ & $2 \cdot 1 \pm 0 \cdot 15$ & $3 \cdot 2 \pm 0 \cdot 27$ \\
\hline
\end{tabular}

comparable with those described by Van Amerlsvoort et al. ${ }^{3}$

Binding in the presence of sodium cyanoborohydride is saturated at 10 hours. ${ }^{9}$ The binding of acetaldehyde to liver plasma membrane vesicles was concentration dependent (Fig. 1) but initial experiments showed the data were not compatible with a single class of binding sites. The Scatchard plot indicated more than one binding affinity for acetaldehyde. The data from each binding study were therefore fitted to three different binding curves using non-linear regression and the best fits on each occasion were determined by calculating the $F$ ratio from the residual sums of squares and comparing this to tabulated values of the distribution of $F$. This was performed on a Hewlett Packard 9845A computer using a program kindly written and supplied by Dr P England of the Department of Biochemistry, University of Bristol.

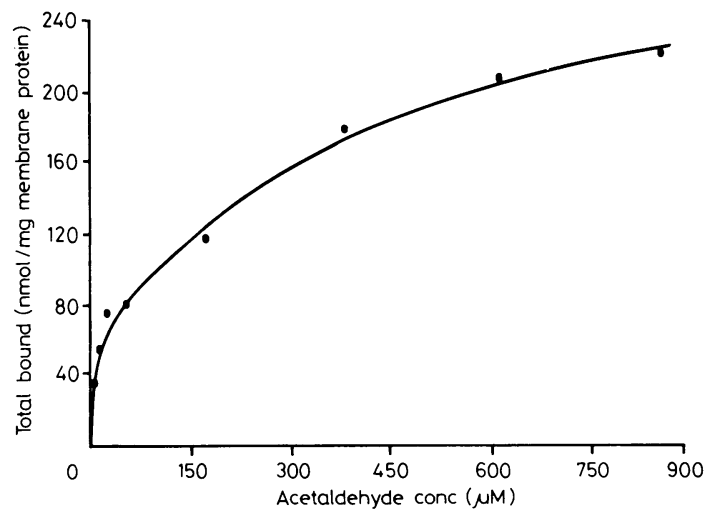

Fig. 1 Shape of the binding curve best fits the equation Amount bound $=$

$$
\frac{B t_{1}}{I+\left(K d_{1} /[\text { acetaldehyde }]\right)}+\frac{B t_{2}}{l+\left(K d_{2} / \text { [acetaldehyde }\right)}
$$

indicating two classes of binding sites on plasma membrane proteins. 
The theoretical binding curves used in the comparison were:

(1) Single class of binding site, where

Amount bound $=$

$$
\frac{\mathrm{Bt}_{1}}{1+\left(\mathrm{Kd}_{1} /[\text { acetaldehyde }]\right)}
$$

(2) Two classes of binding sites, where

Amount bound =

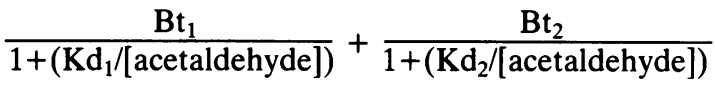

(3) One class of binding site superimposed on a constant non-specific binding, where

Amount bound =

$$
\frac{\mathrm{Bt}}{1+(\mathrm{Kd} /[\text { acetaldehyde] })}+\mathrm{S} \text { [acetaldehyde] }
$$

$\mathrm{Bt}=$ total bound

$\mathrm{Kd}=$ dissociation constant

$\mathrm{S}=$ slope of line of non-specific binding.

In all experiments the equation for a single class of binding sites proved to be statistically a worse fit than those given by equations (2) or (3). In one experiment equation (3) gave statistically as good a fit at the 5\% probability level as the two binding site equation (2), but the majority (five out of six) of experiments indicated a better fit for the two classes of binding site equation. The data presented have therefore been derived from this curve.

The mean binding parameters \pm standard error of the mean for the binding of acetaldehyde to liver plasma membrane proteins at concentration of 0 to 1 millimolar acetaldehyde were

Class 1 sites: $\mathrm{Bt}=18 \pm 9 \cdot 2 \mathrm{nmol}$ of acetaldehyde per $\mathrm{mg}$ membrane of protein. $\mathrm{Kd} 2.08 \pm 0.96 \mu \mathrm{M}$.
Class 2 sites: $\mathrm{Bt}=140 \pm 35 . \mathrm{Kd}=627 \pm 76 \mu \mathrm{M}$.

Because the high affinity binding sites were saturated at concentrations of acetaldehyde less than 100 micromolar, and because the concentration of acetaldehyde found in the serum of patients abusing alcohol are significantly less than 100 micromolar, all subsequent binding studies were performed using acetaldehyde concentrations of $0-100$ micromolar. These and subsequent data were analysed using the single class binding site curve (Equation 1). Thus, at 'physiological' concentrations of acetaldehyde, the total bound at saturation was $38 \pm 7.7 \mathrm{nmol} / \mathrm{mg}$ membrane protein and the mean binding constant was $13 \cdot 2 \pm 4 \cdot 1 \mu \mathrm{M}$ $(n=7)$.

The effects of acetaldehyde on hepatocyte metabolism are illustrated in Figure 2.

As can be seen from Figure 2, urea synthesis from alanine by the isolated rat hepatocytes is uninfluenced by the presence of acetaldehyde in any concentration used. Similarly, glucose production rate is uninfluenced by acetaldehyde in concentrations up to $10 \mathrm{mM}$. There is, however, a slight fall off in glucose production when grossly unphysiological concentrations of acetaldehyde from $15 \mathrm{mM}$ upwards are used.

Urea synthesis and gluconeogenesis involve cytoplasmic and mitochondrial enzyme pathways and are highly sensitive indices of the cell's functional integrity.

Figure 3 indicates that although acetaldehyde binds to the liver cell membranes there is no consequential effect on gross membrane function in whole liver cells as assessed by alanine transport which remains unchanged. Similarly, there is no increase in the leakage of lactate dehydrogenase above control levels of $10 \%$.
Fig. 2 Urea and glucose production measured after 40 minutes' incubation using 10 mM alanine as substrate. Urea production by cells from fed rats was measured as ammonia after incubation of sample with urease. Final protein concentration in incubation mixture was $7.9 \mathrm{mg} / \mathrm{ml}$. Glucose production by cells from overnight fasted rats were pre-incubated for 10 minutes with acetaldehyde. Final protein concentration in incubation mixture was $5 \cdot 2 \mathrm{mg} / \mathrm{ml}$.

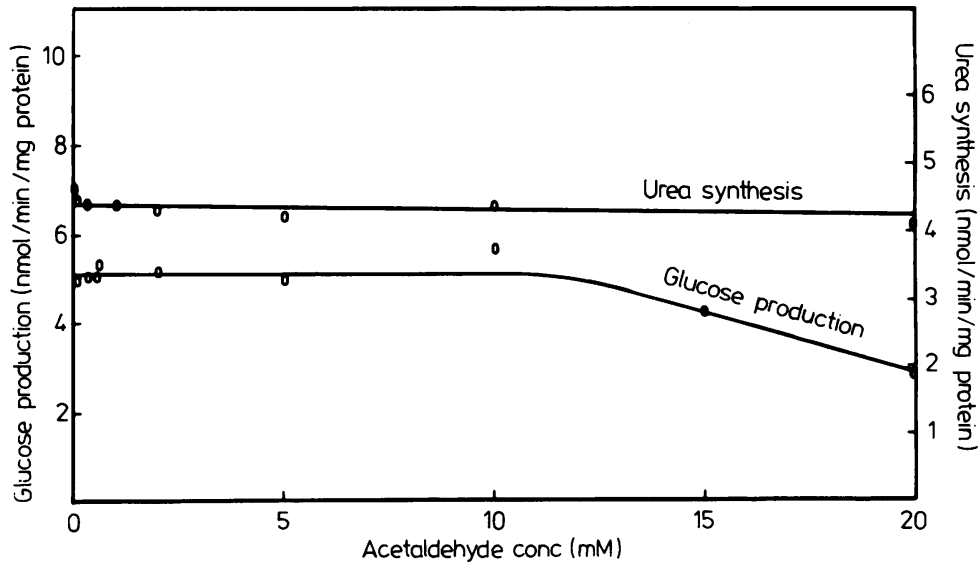


Fig. 3 Transport of alanine into hepatocytes and leakage of $L D H$ are not influenced by the presence of acetaldehyde in concentrations used.

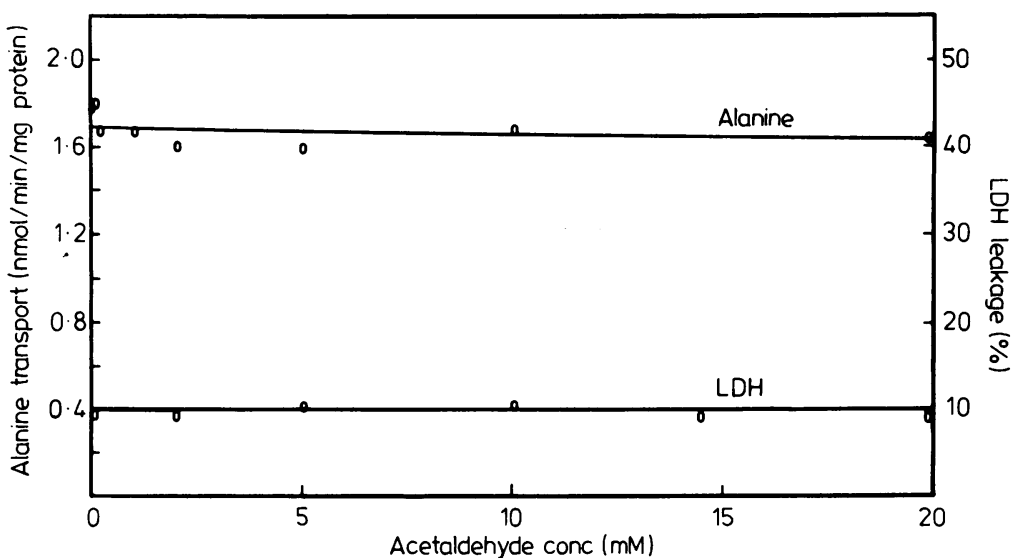

\section{Discussion}

Purified liver plasma membrane vesicles have been used to assess the binding of acetaldehyde to the proteins of the liver plasma membrane. The preparation used gave a five to six-fold concentration of plasma membrane vesicles compared with whole liver homogenate as assessed by membrane markers but there was some contamination with endoplasmic reticulum. Studies by others ${ }^{17}$ have indicated that $70 \%$ of the vesicles prepared by this method are orientated as in vivo - that is, external surface of membranes outwards.

Under the conditions of the binding experiments, however, where an incubation time of 10 hours was used, the vesicular structure of the plasma membranes must have been lost. Binding would occur to both external and internal surfaces of the membranes. Using this preparation, it was shown that acetaldehyde does bind to rat liver cell plasma membranes. At concentrations of acetaldehyde equivalent to those found in alcohol abuse (less than 100 micromolar), the dissociation constant of this binding is 13 and approximately $38 \mathrm{nmol}$ acetaldehyde are bound per milligram of plasma membrane protein. The reductive methylation reaction with sodium cyanoborohydrite would suggest that the binding occurred through the intermediary formation of a Schiff's base. Similar binding of acetaldehyde to haemoglobin has been shown to occur. ${ }^{18}$ The adduction of acetaldehyde with haemoglobin accounts for the raised levels of minor electrophoretic variants of haemoglobin to be found in alcohol abuse. Stephens et al ${ }^{18}$ also showed that the adduction products of haemoglobin with acetaldehyde were stable and that such adduction had no effect on the function of haemoglobin as assessed by its oxygen affinity.
We have studied the effect of acetaldehyde on the There was no effect of acetaldehyde in concentrations up to $20 \mathrm{mM}$ on urea synthesis by the hepatocytes. Gluconeogenesis, a sensitive marker of the cell's functional integrity, was not impaired until grossly unphysiological concentrations of acetaldehyde of greater than $10 \mathrm{mM}$ were reached.

In alcohol abuse, serum acetaldehyde levels can reach $50 \mu \mathrm{M}^{19}$ which is well within the range of concentrations used here (and even this level may be an overestimate $\left.{ }^{20}\right)$. Tissue concentrations of acetaldehyde cannot be accurately measured by .current techniques. Acetaldehyde is, however, a highly volatile, soluble, and freely diffusable molecule so that there is no reason to believe that acetaldehyde concentrations greater than those used in this study are likely to occur.

Gross membrane integrity and function as assessed by the leakage of lactate dehydrogenase and the transport of alanine respectively were unimpaired even at concentrations of acetaldehyde of $20 \mathrm{mM}$.

We suggest that these experiments indicate that acetaldehyde does not act as a direct metabolic poison on the liver cell. Although non-enzymic, adduction of acetaldehyde to the hepatocyte plasma membranes produces no detectable effect on the gross function of the membrane, the effects on the membrane structure have yet to be defined. Similarly, changes in the proteins of the erythrocyte membrane caused by acetaldehyde adduction may not affect membrane function, but are thought to result in the structural changes which are manifest in alcohol abuse as macrocytes. ${ }^{21}$ Such minor structural alterations in hepatocyte membranes may be detectable by the immune system and trigger an immunological response. metabolism of isolated rat hepatocytes in this study. 
The results of this study are compatible with the hypothesis that any injurious effect of acetaldehyde on the liver may be mediated via the immune system and is unlikely to have a direct toxic effect on cellular metabolism.

\section{References}

1 Cochrane AGM. Moussouros A, Portman B et al. Lymphocyte cytotoxicity for isolated hepatocytes in alcoholic liver disease. Gastroenterology 1977; 72: 918-23.

2 Kanagasundaram N, Leevy CM. Ethanol, immune reactions and the digestive system. Clin Gastroenterol 1981; 10: 295-306.

3 Van Amelsvoort JMM. Sips HJ, Van Dam K. Sodium dependent alanine transport in plasma membrane vesicles from rat liver. Biochem J 1978; 174: 1083-6.

4 Samson M, Fehlmann M. Plasma membrane vesicles from isolated hepatocytes retain the increase of aminoacid transport induced by dibutyryl cyclic AMP in intact cells. Biochem Biophys Acta 1982; 687: 35-41.

5 Hepel LA, Himlow RJ. Methods in enzymology. Vol II. New York: Academic Press, 1955: 546.

6 Swanson MA. Methods in enzymology. Vol II. New York: Academic Press, 1955: 541-3.

7 Lowry OH, Rosebrough NJ, Farr AL, Randall RJ. Protein measurements with the Folin phenol reagent. J Biol Chem 1951; 193: 265-75.

8 Borch RF, Bernstein MD, Durst HD. Cyanohydridoborate anion as a selective reducing agents. $J \mathrm{Am}$ Chem Soc 1971; 93: 2897-904.

9 Jentoft N. Dearborn DG. Labeling of proteins by reductive methylation using sodium cyanoborohydride. J Biol Chem 1979; 254: 4359-65.

10 Jentoft N, Dearborn DG. Protein labelling by reductive methylation with sodium cyanoborohydride: effect of cyanide and metal ions on the reaction. Anal Biochem 1980; 106: 186-90.

11 Berry MN. Friend DS. High yield preparation of isolated rat liver parenchymal cells. J Cell Biol 1969; 43: 506-20.

12 Krebs HA. Cornell NW. Lund P. Hems R. Isolated liver cells as experimental material. In: Lundquist F. Tygstrup N, eds. Regulation of hepatic metabolism. Alfred Benzon Symposium VI. Copenhagen: Munksgaard, 1974: 726.

13 Kirsten E, Gerez C. Kirsten R. Eine enzymatische Microbestimmung des Ammoniaks, geeignet für Extrakte tierischer Gewebe und Flüssigkeiten. Biochem Zeit 1963; 337: 312-19.

14 Krebs HA, Bennett DAH, de Gasquet P. Gascoyne T, Yoshida $T$. Renal gluconeogenesis. The effects of diet on the gluconeogenic capacity of rat kidney cortex slices. Biochem J 1963; 86: 22-7.

15 Sear JW, NcGivan JD. Cytotoxicity of IV anaesthetic agents on the isolated rat hepatocyte. Br J Anaesth 1979; 51: 733-9.

16 Joseph SK, Bradford NM. McGivan JD. The characteristics of the transport of alanine, serine and glutamine across the plasma membrane of the isolated rat liver cell. Biochem J 1978; 176: 827-36.

17 Sips HJ, Brown D, Oonk R, Orci L. Orientation of rat liver plasma membrane vesicles. A biochemical and ultrastructural study. Biochem Biophys Acta 1982; 692: 442-54.

18 Stevens VJ, Fantl WJ, Newman CB, Sims RV, Cerami A, Peterson CM. Acetaldehyde adducts with haemoglobin. J Clin Invest 1981; 67: 361-9.

19 Korsten MA, Matsuzaki S, Feinman L, Lieber CS. High blood acetaldehyde levels after ethanol administration. Difference between alcoholic and nonalcoholic subjects. N Engl J Med 1975; 292: 386-9.

20) Eriksson CJP. Elevated blood acetaldehyde levels in alcoholics and their relatives: a re-evaluation. Science 1980; 207: 1383-4.

21 Gaines KC. Salhany JM, Tuma DJ, Sorrell MF. Reaction of acetaldehyde with human erythrocyte membrane proteins. FEBS Lett 1977; 75: 115-9. 